\title{
A cross-sectional analysis of video games and attention deficit hyperactivity disorder symptoms in adolescents Philip A Chan*1 and Terry Rabinowitz ${ }^{2}$
}

Address: ${ }^{1}$ Department of Internal Medicine, Rhode Island Hospital, Brown University, Providence, RI, 02912, USA and ${ }^{2}$ Department of Psychiatry, Fletcher Allen Healthcare, and the University of Vermont College of Medicine, Burlington, VT, 05401, USA

Email: Philip A Chan* - Pchan@lifespan.org; Terry Rabinowitz - Terry.Rabinowtiz@vtmednet.org

* Corresponding author

Published: 24 October 2006

Annals of General Psychiatry 2006, 5:16 doi:10.1186/1744-859X-5-16
Received: 21 March 2006

Accepted: 24 October 2006

This article is available from: http://www.annals-general-psychiatry.com/content/5/l/16

(C) 2006 Chan and Rabinowitz; licensee BioMed Central Ltd.

This is an Open Access article distributed under the terms of the Creative Commons Attribution License (http://creativecommons.org/licenses/by/2.0), which permits unrestricted use, distribution, and reproduction in any medium, provided the original work is properly cited.

\begin{abstract}
Background: Excessive use of the Internet has been associated with attention deficit hyperactivity disorder (ADHD), but the relationship between video games and ADHD symptoms in adolescents is unknown.

Method: A survey of adolescents and parents $(n=72$ adolescents, 72 parents) was performed assessing daily time spent on the Internet, television, console video games, and Internet video games, and their association with academic and social functioning. Subjects were high school students in the ninth and tenth grade. Students were administered a modified Young's Internet Addiction Scale (YIAS) and asked questions about exercise, grades, work, and school detentions. Parents were asked to complete the Conners' Parent Rating Scale (CPRS) and answer questions regarding medical/psychiatric conditions in their child.
\end{abstract}

Results: There was a significant association between time spent playing games for more than one hour a day and YIAS $(p<0.001)$, overall grade point average $(p \leq 0.019)$, and the "Inattention" and "ADHD" components of the CPRS ( $p \leq 0.001$ and $p \leq 0.020$, respectively). No significant association was found between body mass index (BMI), exercise, number of detentions, or the "Oppositional" and "Hyperactivity" components of CPRS and video game use.

Conclusion: Adolescents who play more than one hour of console or Internet video games may have more or more intense symptoms of ADHD or inattention than those who do not. Given the possible negative effects these conditions may have on scholastic performance, the added consequences of more time spent on video games may also place these individuals at increased risk for problems in school.

\section{Background}

The introduction of the telegraph in the nineteenth century ushered in a new era of communication and social development. Further advances in technology led to the creation of the telephone, radio, and television. Recently, the Internet has become the pinnacle of interchange in the modern world and facilitates many different modes of communication. Each generation has raised concerns regarding the negative impact of media on social skills and personal relationships. The Internet appeals to adolescents for many reasons and has become a social con- 
nection for many with uses including messaging, e-mail, gaming, education, and music.

The Internet and other media types are reported to have important social and mental health effects in adolescents. The association between television viewing and obesity, attention disorders, school performance, and violence has been reported [1-6]. Likewise, recent studies on obsessive Internet use called "Internet Addiction" have shown negative effects on social health $[7,8]$. A significant relationship between Internet use and attention deficit hyperactivity disorder (ADHD) has also been shown in elementary school children [9]. Other studies have reported the similarities between computer video game addiction and pathological gambling or substance dependence [10-12].

The effect of video games on adolescents is not well characterized despite a growing body of evidence demonstrating their addictive nature and popularity [13-15]. Indeed, video game use may exceed that of television use in children [16]. In pre-adolescent teenagers, obesity has been linked to increasing time spent on video games, but other studies have disputed this finding in different populations [17-19]. Most studies of mental health and media use did not specifically examine video games, but included them as a subset of television or Internet use. One extensively studied area is the content of video games and their relationship to subsequent aggressive behavior in children $[14,20-22]$. Other case reports have documented associations between video games and various conditions such as epilepsy, musculoskeletal disorders, and deep vein thrombosis, although the strength of these associations has not yet been established [23-27].

Despite recent negative attention, some studies have shown possible positive effects of video games on development. One study by $\mathrm{Li}$ et al. found a positive association between motor development and cognitive behavior in preschool age children [28]. Other studies have reported that previous computer game experience enhances laparoscopic simulator performance in physicians [29]. In addition, video games are more frequently being used as adjuncts to learning and training in various settings, including medical education $[30,31]$.

The term "video games" does not always differentiate between console and Internet/computer video games but instead, suggests a loose clustering. Console video games include Nintendo, Sony Playstation, Microsoft Xbox, and others. Internet video games refer to computer games played online in a community setting with other players. Although similar in nature, several important differences exist. Console games can be played with other people, but most games are "single player" and are meant to be played alone. Internet games however, are designed for "multiplayer" use and are played with others online, usually at distant sites. Console games are less expensive than Internet games, and do not require a computer. The genre of video games played on the Internet versus console games also differs in content. Console game themes include sports, action, strategy, family, puzzle, role-playing games, and simulation, while video game themes designed for Internet use are more specific and are mainly action and strategy. The video game market, regardless of type, is a multi-billion dollar industry that generally targets children and adolescents.

The relationship between video games and ADHD is unknown. The incidence of ADHD continues to rise and is a significant challenge on medical, financial, and educational resources $[32,33]$. ADHD is a complex disorder that often requires input from the affected child or adolescent, teachers, parents, and physicians in order to be diagnosed correctly and treated successfully [34]. The Conners' Parent Rating Scale (CPRS) [35] is the most widely used instrument to aid in the diagnosis of children with ADHD. The CRS comprises both a parent and teacher questionnaire, and includes a number of components including oppositional behavior, hyperactivity, inattention, and ADHD.

This study examined the relationship between video game use and symptoms of ADHD. Other parameters studied included body mass index (BMI), school grades, work, detentions, and family situation.

\section{Method \\ Design and procedures}

After receiving IRB approval, subjects were recruited from a local high school in Vermont. Permission from school officials was obtained and contact was made with the guidance office and school teachers. Surveys were distributed to all $9^{\text {th }}$ and $10^{\text {th }}$ grade students at the school $(\mathrm{n}=$ 221). The survey included sections for students (five pages) and parents (two pages) to complete independently, as well as a consent form which needed to be signed by both the student and parent for participation in the study. All survey data was anonymous. Surveys were collected $(n=162)$ through the school Guidance Office. Eighteen surveys were omitted due to incomplete responses. The final subject pool comprised 144; 72 each from parents and students. Original power calculations were based on a reported $10 \%$ prevalence of psychiatric disorders in the adolescent population and called for a total of 200 students for a power of 0.80 . However, statistically significant results were reached after analysis of 144 completed questionnaires and led us to conclude that the study could be terminated at that point. 
Table I: Subject Demographics

\begin{tabular}{lccc}
\hline Population Characteristics & Males $(\mathrm{n}=3 \mathrm{I})$ & Females $(\mathrm{n}=4 \mathrm{I})$ & Total $(\mathrm{n}=72)$ \\
\hline Students who work & $26 \%(8)$ & $37 \%(15)$ & $32 \%(23)$ \\
Parents married & $87 \%(27)$ & $90 \%(37)$ & $89 \%(64)$ \\
Divorced, Separated, other & $13 \%(4)$ & $10 \%(4)$ & $11 \%(8)$ \\
Detention in the last month & $19 \%(6)$ & $10 \%(4)$ & $14 \%(10)$ \\
Physical fight in the last year & $3 \%(1)$ & $2 \%(1)$ & $3 \%(2)$ \\
Drink alcohol weekly & $3 \%(1)$ & $7 \%(3)$ & $6 \%(4)$ \\
Smoke daily & $0 \%(0)$ & $2 \%(1)$ & $1 \%(1)$ \\
Diagnosed ADD/ADHD & $6 \%(2)$ & $0 \%(0)$ & $3 \%(2)$ \\
Diagnosed Depression/Anxiety & $3 \%(I)$ & $7 \%(3)$ & $6 \%(4)$ \\
\hline
\end{tabular}

\section{Measures}

Time spent playing videos games, watching television, or using the Internet was assessed using a time scale of less than one hour, one to two hours, three to four hours, or greater than four hours. The student survey material included Young's Internet Addiction Scale, modified for video game use (YIAS-VG; internal consistency, alpha = 0.82 ) [36]. This scale was validated in previous studies for Internet addictive qualities [13,36]. The questions reflect the negative impact of video games on social functioning and relationships including excessive video game use, neglecting work and social life, anticipation, lack of control, and salience. Parents were surveyed using the Conners' Parent Rating Scale (CPRS; internal consistency, $\mathrm{r}=$ 0.57) [35]. The CPRS divides behavior into four categories: oppositional, hyperactivity, inattention, and ADHD. Other items included gender, family situation, exercise per week, detentions in the last month, work, and academic performance. Family situation was defined as either living with married parents or living with one parent who was divorced or separated. Academic performance was assessed by overall grade point average and last grade earned in both mathematics and English classes given that these two areas are accepted as core competencies in any high school curriculum.

\section{Data analysis}

The dependent variables reported in numerical format (BMI, grades, YIAS-VG, CPRS) were analyzed using the student's t-test and the Mann-Whitney test. The latter method is based on median values and is the preferred method when testing small sample sizes. Data reported as "yes/no" (sex, work, detentions, exercise, and family situation) was analyzed using the chi-square test. Results were considered significant if $\mathrm{p} \leq 0.05$. Time spent playing video games, watching television, and using the internet was the independent variable. The time intervals compared were for student who spent less than one hour or greater than one hour on a particular activity. The one hour cutoff was used because it gave a more even distribution of sample sizes between the two groups although other time intervals were also compared.

\section{Results}

The study cohort comprised 72 students; 31 males and 41 females in the ninth and tenth grade. Average age was 15.3 \pm 0.7 years. Subject demographics are shown in Table 1 . Almost 32\% of students worked and $89 \%$ had parents who were married. Ten students had at least one detention in the last month and two students were involved in a physical fight in the last year. Four students consumed alcohol and one student reported daily smoking. Two students reported a diagnosis of ADHD and four reported having depression and/or anxiety.

The mean BMI for adolescents who watched less than one hour of television per day was $20.28 \pm 2.33$ and $22.11 \pm$ 4.01 for those who watched more than one hour of television $(\mathrm{p}=0.017$, Table 2). There was a trend towards a higher BMI for adolescents spending more than one hour playing video games, but these results were not significant. No association was found between BMI and time spent on the Internet.

Table 2: Body Mass Index

\begin{tabular}{|c|c|c|c|c|c|c|c|c|c|}
\hline & & \multicolumn{2}{|c|}{ INTERNET } & \multicolumn{2}{|c|}{ TELEVISION } & \multicolumn{2}{|c|}{$\begin{array}{l}\text { CONSOLE VIDEO } \\
\text { GAMES }\end{array}$} & \multicolumn{2}{|c|}{$\begin{array}{c}\text { INTERNET VIDEO } \\
\text { GAMES }\end{array}$} \\
\hline & & $<$ I hour & $\geq \mathbf{I}$ hour & $<$ I hour & $\geq \mathbf{I}$ hour & $<$ I hour & $\geq \mathbf{I}$ hour & $<$ I hour & $\geq$ I hour \\
\hline \multirow{3}{*}{$\begin{array}{l}\text { Body Mass } \\
\text { Index }\end{array}$} & Mean & 22.09 & 21.01 & 20.28 & 22.11 & 21.06 & 23.77 & 21.31 & 22.62 \\
\hline & & \pm 4.12 & \pm 3.15 & \pm 2.33 & \pm 4.01 & \pm 3.13 & \pm 5.19 & \pm 3.59 & \pm 3.73 \\
\hline & $\mathrm{p}$-value & 0.23 & & 0.017 & & 0.12 & & 0.35 & \\
\hline
\end{tabular}


Students who played video games for more than one hour had significant increases in scores on the YIAS-VG ( $\mathrm{p}<$ 0.001 for console and Internet video games, Table 3 ). Other activities were associated with a trend toward increased YIAS-VG, but were not significant.

There was a significant increase in inattentive ( $\mathrm{p} \leq 0.001$ for both Internet and console video games) and ADHD ( $\mathrm{p}$ $=0.018$ and 0.020 for console and Internet games, respectively) behavior in those who played video games for more than one hour (Table 3). No significant association was found between the hyperactivity or oppositional components of the CPRS and video game use. No significant relationship was found in any of the four categories and Internet or television use.

There was a trend toward lower grades in students who surf the Internet and play video games for more than one hour, but these results were not significant (Table 4). However, significantly lower grades were found between students who play video games for more than one hour and overall grade point average (GPA, $\mathrm{p}=0.019$ and 0.009 for console and Internet games, respectively).

Males were significantly more likely than females to spend greater than one hour a day playing console or internet video games $(\mathrm{p}<0.001$ and $\mathrm{p}=0.003$, respectively). Twenty males reported playing video games for more than one hour a day versus only one female adolescent reported playing internet video games for more than one hour. There was no significant relationship between gen- der and time spent watching television or on the Internet. We also found no significant association between time spent on any media form and students who worked, had married parents, received more detentions per month, or exercised more frequently.

\section{Discussion}

ADHD among children and adolescents has been attributed to both genetic and environmental factors[37]. Of the media influences, only excessive Internet use has been reported to be associated with ADHD. The diagnosis of ADHD relies on input from teachers, parents, and physicians. This study found an increase in ADHD and inattention symptoms in adolescents who play video games for more than one hour a day.

The prevalence of ADHD in adolescents is reported to be $4-7 \%[37,38]$. This study found a prevalence of $8.3 \%$ based on a reported diagnosis by a parent. It was not possible to determine the actual diagnosis of ADHD based only on the raw scores of the CRPS. More or more severe symptoms of inattention and ADHD behavior were found in students who played video games for more than one hour, but further study is needed to more clearly understand the association between video games and ADHD. It is unclear whether playing video games for more than one hour leads to an increase in ADHD symptoms, or whether adolescents with ADHD symptoms spend more time on video games.

Table 3: Behavioral Symptoms

\begin{tabular}{|c|c|c|c|c|c|c|c|c|c|}
\hline & & \multicolumn{2}{|c|}{ INTERNET } & \multicolumn{2}{|c|}{ TELEVISION } & \multicolumn{2}{|c|}{$\begin{array}{c}\text { CONSOLE VIDEO } \\
\text { GAMES }\end{array}$} & \multicolumn{2}{|c|}{$\begin{array}{c}\text { INTERNET VIDEO } \\
\text { GAMES }\end{array}$} \\
\hline & & $<$ I hour & $\geq \mathbf{I}$ hour & $<$ I hour & $\geq \mathbf{I}$ hour & $<$ I hour & $\geq \mathbf{I}$ hour & $<$ I hour & $\geq \mathbf{I}$ hour \\
\hline \multirow[t]{3}{*}{ Young's Addiction Scale } & Mean & 12.80 & 14.50 & 9.70 & 16.00 & 10.10 & 34.30 & 10.20 & 38.60 \\
\hline & & \pm 11.00 & \pm 16.40 & \pm 14.60 & \pm 13.80 & \pm 10.70 & \pm 14.80 & \pm 10.40 & \pm 13.40 \\
\hline & $\mathrm{p}$-value & 0.804 & & 0.040 & & $<0.001$ & & $<0.001$ & \\
\hline \multirow[t]{3}{*}{ Conner's Scale: Oppositional } & Mean & 1.77 & 2.66 & 2.36 & 2.23 & 2.33 & 2.00 & 2.33 & 1.89 \\
\hline & & \pm 2.36 & \pm 2.73 & \pm 2.08 & \pm 2.85 & \pm 2.69 & \pm 2.05 & \pm 2.72 & \pm 1.45 \\
\hline & $\mathrm{P}$-value & 0.096 & & 0.397 & & 0.917 & & 0.826 & \\
\hline \multirow{3}{*}{ Conner's Scale: Inattention } & Mean & 1.29 & 1.68 & 1.72 & 1.40 & 1.00 & 4.36 & 1.16 & 4.00 \\
\hline & & \pm 2.67 & \pm 2.51 & \pm 2.62 & \pm 2.57 & \pm 1.60 & \pm 4.59 & \pm 2.25 & \pm 3.39 \\
\hline & $\mathrm{p}$-value & 0.289 & & 0.311 & & 0.001 & & $<0.001$ & \\
\hline \multirow[t]{3}{*}{ Conner's Scale: Hyperactivity } & Mean & 1.19 & 1.49 & 1.40 & 1.34 & 1.39 & 1.18 & $\mathrm{I} .44$ & 0.78 \\
\hline & & \pm 1.14 & \pm 2.11 & \pm 1.32 & \pm 1.96 & \pm 1.82 & \pm 1.40 & \pm 1.79 & \pm 1.39 \\
\hline & $\mathrm{p}$-value & 0.901 & & 0.397 & & 0.800 & & 0.142 & \\
\hline \multirow[t]{3}{*}{ Conner's Scale: ADHD } & Mean & 3.32 & 4.88 & 4.64 & 3.98 & 3.59 & 7.64 & 3.78 & 7.22 \\
\hline & & \pm 3.75 & \pm 5.13 & \pm 4.66 & \pm 4.64 & \pm 3.89 & \pm 6.79 & \pm 4.26 & \pm 6.12 \\
\hline & $\mathrm{P}$-value & 0.115 & & 0.343 & & 0.018 & & 0.020 & \\
\hline
\end{tabular}

ADHD = Attention deficit hyperactivity disorder 
Table 4: Academic Performance

\begin{tabular}{|c|c|c|c|c|c|c|c|c|c|}
\hline & & \multicolumn{2}{|c|}{ INTERNET } & \multicolumn{2}{|c|}{ TELEVISION } & \multicolumn{2}{|c|}{$\begin{array}{c}\text { CONSOLE VIDEO } \\
\text { GAMES }\end{array}$} & \multicolumn{2}{|c|}{$\begin{array}{c}\text { INTERNET VIDEO } \\
\text { GAMES }\end{array}$} \\
\hline & & $<$ I hour & $\geq \mathbf{I}$ hour & $<$ I hour & $\geq \mathbf{I}$ hour & $<$ I hour & $\geq \mathbf{I}$ hour & $<$ I hour & $\geq \mathbf{I}$ hour \\
\hline \multirow[t]{3}{*}{ Last Grade in Math } & Mean & 3.422 & 3.308 & 3.306 & 3.383 & 3.393 & 3.132 & 3.37 & 3.259 \\
\hline & & \pm 0.689 & \pm 0.748 & \pm 0.687 & \pm 0.744 & \pm 0.706 & \pm 0.805 & \pm 0.705 & \pm 0.863 \\
\hline & $\mathrm{p}$-value & 0.547 & & 0.422 & & 0.255 & & 0.754 & \\
\hline \multirow[t]{3}{*}{ Last Grade in English } & Mean & 3.263 & 3.201 & 3.217 & 3.232 & 3.254 & 3.067 & 3.267 & 2.963 \\
\hline & & \pm 0.721 & \pm 0.662 & \pm 0.608 & \pm 0.723 & \pm 0.659 & \pm 0.829 & \pm 0.638 & \pm 0.934 \\
\hline & $\mathrm{p}$-value & 0.545 & & 0.727 & & 0.545 & & 0.395 & \\
\hline \multirow[t]{3}{*}{ Overall Grade Point Average } & Mean & 3.686 & 3.523 & 3.626 & 3.567 & 3.668 & 3.002 & 3.668 & 3.00 \\
\hline & & \pm 0.392 & \pm 0.494 & \pm 0.438 & \pm 0.475 & \pm 0.341 & \pm 0.762 & \pm 0.356 & \pm 0.701 \\
\hline & $\mathrm{p}$-value & 0.190 & & 0.735 & & 0.019 & & 0.009 & \\
\hline
\end{tabular}

This study found no association between video games use and oppositional or aggressive behavior. Previous research has shown a positive correlation between violence in video games and aggressive behavior $[4,14,20,21]$. It is possible that video games only lead to this type of behavior in groups prone to violent behavior or in conjunction with other forms of violence in media. The power of this study was not designed to detect such differences, thus no inferences can be made.

The effect of television viewing on BMI has been reported in several studies $[1,2,5,6]$. We found a significant association between increased BMI and watching television for more than one hour. Playing video games for more than one hour was not associated with an increase in BMI. Previous studies found a significant relationship between BMI and video games in younger populations $[18,19]$. Our findings suggest this association may persist into early adolescence.

Time on the Internet was not associated with increased BMI; a trend towards decreasing BMI was found in adolescents who use the Internet for more than one hour. Our findings suggest that current recommendations to limit television and video game times for children should be followed [6].

Both console and Internet video games were associated with an increase in addiction scores as measured by YIASVG. The YIAS-VG assesses the degree to which video games negatively impact different social factors including daily activities, relationships, sleep, and daily thoughts. The increase in YIAS-VG scores imply that playing video games for more than one hour a day does have a negative impact on relationships and daily activity. We did not define a cutoff on the YIAS-VG to identify "excessive" video game use but the scores in our cohort were not high enough to be considered as evidence of "Internet Addiction" [13,36].

GPA was lower in those who played video games for more than one hour. Even though this study cohort had a relatively high overall GPA, the difference between an "A" (less than one hour of video games) versus a "B" (more than one hour of video games) is a significant change in grade. For students who are less academically proficient, this may be especially important. There was also a trend towards a lower GPA in students who watch television for more than one hour. Excessive television has been reported to be associated with poor school performance [6].

This investigation found that playing console and Internet video games for more than one hour a day has negative social and academic effects in adolescents. This association does not depend on being "addicted" to video games or playing for excessive time periods. Furthermore, there was no difference between playing video games on the Internet or on a console system. The intensive nature of video games is likely to cause this time dependent relationship between video games and behavior disorders, regardless of whether it is over the Internet or on a console system.

Several limitations of the study exist. This cross-sectional comparison of video games and ADHD does not allow for cause-effect relationships to be established. Therefore, it is impossible to say whether playing video games leads to an increase in ADHD symptoms, or if adolescents with more ADHD symptoms tend to spend longer times playing video games. Prospective studies to examine this relationship more closely are certainly justified. The subject cohort was also not representative of all groups. The large majority of students who responded to the survey were 
Table 5: UNIVERSITY OF VERMONT STUDENT SURVEY (To be completed individually by student)

\begin{tabular}{|c|c|c|c|}
\hline Age: & Height: & Weight: & \\
\hline Sex: (Circle one) & Male & Female & \\
\hline Last grade in Math Class (as appears on last report card): & $A+A A-B+B-C+C C-D+D D-1$ & & \\
\hline \multirow[t]{2}{*}{ Last grade in English Class (as appears on last report card): } & $A+A A-B+B B-C+C C-D+D D-1$ & & \\
\hline & \multicolumn{2}{|c|}{ Overall average grade (as appears on last report card): } & \\
\hline What is your family situation: & Parents are married or live together & Parents live apart & $\begin{array}{l}\text { Parents are divorced, } \mathrm{Il} \\
\text { with mom or dad }\end{array}$ \\
\hline Average total number of hours a day spent on Internet: (Circle one) & Less than I & $1-2$ & $3-4$ \\
\hline Average total number of hours a day spent on Computer games: (Circle one) & Less than I & $1-2$ & $3-4$ \\
\hline \multicolumn{4}{|l|}{ Favorite game: } \\
\hline \multicolumn{4}{|l|}{ How many detentions have you had in the past month? } \\
\hline Have you been suspended from school in the past year? & YES & NO & If yes, how many times? \\
\hline Have you been in a physical fight in the past year? & YES & NO & If yes, how many times? \\
\hline Have you been arrested in the past year? & YES & NO & If yes, how many times? \\
\hline
\end{tabular}

Do you drink alcohol? (Circle one)

If yes, how many drinks per week on average?

If yes, how many cigarettes per day on average?

$$
\text { YES }
$$

If yes, how many joints per week on average?

Other drugs and amount:

How often do you use alcohol/cigarettes/drugs while playing video games? (Circle one)

SOMETIMES

RARELY

NEVER

Rarely

Occasionally

Frequently

Often

Always Does Not 


3. How often do you prefer the excitement of playing video games to spending time
with your girl/boy friend or family?

are playing video games?

14. How often do you lose sleep due to late-night video games?

15. How often do you feel preoccupied with playing video games when not, or fantasize about doing so?

16. How often do you find yourself saying "just a few more minutes" when playing video games?

17. How often do you try to cut down the amount of time you spend playing video games and fail?

18. How often do you try to hide how long you've been playing video games?

19. How often do you choose to spend more time playing video games over going

20. How often do you feel depressed, moody, or nervous when you are not playing

Qै Subjects were also asked to complete the Beck Depression Inventory

Production note: This article was amended post-publication. For copyright reasons, the Beck Depression Inventory was removed. 
Table 6: UNIVERSITY OF VERMONT PARENT SURVEY (To be completed by the parent/guardian who is most involved in the student's care/daily life)

\begin{tabular}{|c|c|c|c|c|}
\hline Relation to student: (Circle one) & Father & Mother & Legal Guardian & Other (specify): \\
\hline $\begin{array}{l}\text { Number of hours child spends a day on } \\
\text { Internet total: (Circle one) }\end{array}$ & $<1$ & $\mathrm{I}-2$ & $3-4$ & $>4$ \\
\hline $\begin{array}{l}\text { Number of hours a day child spends on } \\
\text { computer games: (Circle one) }\end{array}$ & $<1$ & $\mathrm{I}-2$ & $3-4$ & $>4$ \\
\hline $\begin{array}{l}\text { Number hours a day child spends on } \\
\text { console games (Playstation, Nintendo, } \\
\text { etc.): (Circle one) }\end{array}$ & $<1$ & $\mathrm{I}-2$ & $3-4$ & $>4$ \\
\hline $\begin{array}{l}\text { Number hours a day child spends } \\
\text { watching television: (Circle one) }\end{array}$ & $<1$ & $1-2$ & $3-4$ & $>4$ \\
\hline $\begin{array}{l}\text { Has your son/daughter ever been } \\
\text { diagnosed with: (Circle one) }\end{array}$ & Depression & Anxiety Disorder & ADD/ADHD & Other (specify): \\
\hline \multicolumn{5}{|l|}{ If so, for how many years? } \\
\hline $\begin{array}{l}\text { Does your son/daughter have any other } \\
\text { medical illnesses (diabetes, epilepsy, etc.)? }\end{array}$ & Yes & No & If so, please specify: & \\
\hline $\begin{array}{l}\text { Is your son/daughter currently on any } \\
\text { prescription medications? }\end{array}$ & Yes & No & & \\
\hline \multicolumn{5}{|l|}{ If so, please list medications: } \\
\hline Is your son/daughter: & $\begin{array}{l}\text { NOT TRUE AT ALL } \\
\text { (NEVER, SELDOM) }\end{array}$ & $\begin{array}{l}\text { JUST A LITTLE TRUE } \\
\text { (SOMETIMES) }\end{array}$ & $\begin{array}{l}\text { PRETTY MUCH TRUE } \\
\text { (OFTEN) }\end{array}$ & $\begin{array}{l}\text { VERY MUCH TRUE } \\
\text { (VERY OFTEN) }\end{array}$ \\
\hline \multicolumn{5}{|l|}{ I Inattentive, easily distracted } \\
\hline \multicolumn{5}{|l|}{2 Angry and resentful } \\
\hline \multicolumn{5}{|l|}{$\begin{array}{l}3 \text { Difficulty doing or completing } \\
\text { homework }\end{array}$} \\
\hline \multicolumn{5}{|l|}{4 Always "on the go" } \\
\hline \multicolumn{5}{|l|}{5 Short attention span } \\
\hline \multicolumn{5}{|l|}{6 Argues with adults } \\
\hline \multicolumn{5}{|l|}{7 Fidgets with hands/feet, squirm in seat } \\
\hline \multicolumn{5}{|l|}{8 Fails to complete assignments on time } \\
\hline \multicolumn{5}{|l|}{$\begin{array}{l}9 \text { Hard to control in malls or grocery } \\
\text { shopping }\end{array}$} \\
\hline \multicolumn{5}{|l|}{$\begin{array}{l}\text { I0 Messy or disorganized at home or } \\
\text { school }\end{array}$} \\
\hline \multicolumn{5}{|l|}{ I I Loses temper } \\
\hline \multicolumn{5}{|l|}{$\begin{array}{l}\text { I } 2 \text { Needs close supervision to get through } \\
\text { assignments }\end{array}$} \\
\hline \multicolumn{5}{|l|}{$\begin{array}{l}13 \text { Only attends if it is something he/she is } \\
\text { very interested in }\end{array}$} \\
\hline \multicolumn{5}{|l|}{$\begin{array}{l}\text { I } 4 \text { Runs or climbs excessively in situations } \\
\text { where it is inappropriate }\end{array}$} \\
\hline \multicolumn{5}{|l|}{$\begin{array}{l}\text { I } 5 \text { Distractibility or attention span a } \\
\text { problem }\end{array}$} \\
\hline \multicolumn{5}{|l|}{16 Irritable } \\
\hline \multicolumn{5}{|l|}{$\begin{array}{l}17 \text { Avoids, expresses reluctance about, or } \\
\text { has difficulty engaging in tasks that } \\
\text { require sustained mental effort (such as } \\
\text { school work or homework) }\end{array}$} \\
\hline \multicolumn{5}{|l|}{ I 8 Restless in the "squirmy" sense } \\
\hline \multicolumn{5}{|l|}{$\begin{array}{l}19 \text { Gets distracted when given instruction } \\
\text { to do something }\end{array}$} \\
\hline \multicolumn{5}{|l|}{$\begin{array}{l}20 \text { Actively defies or refuses to comply } \\
\text { with adults' requests }\end{array}$} \\
\hline \multicolumn{5}{|l|}{ 2I Has trouble concentrating in class } \\
\hline \multicolumn{5}{|l|}{$\begin{array}{l}22 \text { has difficulty waiting in lines or } \\
\text { awaiting turn in games or group situations }\end{array}$} \\
\hline \multicolumn{5}{|l|}{$\begin{array}{l}23 \text { Leaves seat in classroom or other } \\
\text { situation in which remaining seated is } \\
\text { expected }\end{array}$} \\
\hline \multicolumn{5}{|l|}{$\begin{array}{l}24 \text { Deliberately does things that annoy } \\
\text { other people }\end{array}$} \\
\hline \multicolumn{5}{|l|}{$\begin{array}{l}25 \text { Does not follow through on } \\
\text { instructions and fails to finish schoolwork, } \\
\text { chores, or duties in the workplace }\end{array}$} \\
\hline \multicolumn{5}{|l|}{$\begin{array}{l}26 \text { has difficulty playing or engaging in } \\
\text { leisure activities quietly }\end{array}$} \\
\hline 27 Easily frustrated in efforts & & & & \\
\hline
\end{tabular}

Thank you for taking part in our survey. All results are confidential. Please contact Philip Chan (research coordinator) at Philip.Chan@uvm.edu anytime with questions.

PLEASE PLACE FINISHED SURVEY IN A SEALED ENVELOPE 
Caucasian, not involved with drugs or alcohol, had married parents, and did well in school. Thus, the association between video games and ADHD in other cohorts cannot be inferred. This study was designed to analyze adolescents who spent more than one hour of time playing video games. It would be interesting to examine the latter cohort in more detail to determine if there is a linear relationship between time spent playing video games and ADHD symptoms or academic performance, or if some other relationship exists among those who spend excessive time on these activities.

\section{Conclusion}

To our knowledge, this is the first study to find an association between video game use and ADHD symptoms in adolescents. Assessment of ADHD risk factors often involves identification of home and academic environmental factors. Parental relationships, early childhood development factors (i.e. preterm delivery), and excessive Internet use are associated with ADHD later in life. Identification of these and other risk factors that contribute to ADHD will lead to prevention and earlier treatment strategies.

\section{Production note}

This article was amended post-publication. The Beck Depression Inventory was originally listed in Appendix A (Table 5), but has been removed for copyright reasons.

\section{Acknowledgements}

We thank Diantha Howard for statistical assistance and Juliette Chan for her support. We are grateful to Linda Barnes and Sarah Smith Conroy for their assistance.

\section{References}

I. Hancox RJ, Poulton R: Watching television is associated with childhood obesity: but is it clinically important? Int J Obes (Lond) 2005.

2. Marshall SJ, Biddle SJ, Gorely T, Cameron N, Murdey I: Relationships between media use, body fatness and physical activity in children and youth: a meta-analysis. Int J Obes Relat Metab Disord 2004, 28( I 0): 1238-1246.

3. Christakis DA, Zimmerman FJ, DiGiuseppe DL, McCarty CA: Early television exposure and subsequent attentional problems in children. Pediatrics 2004, I I3(4):708-7I3.

4. Browne KD, Hamilton-Giachritsis C: The influence of violent media on children and adolescents:a public-health approach. Lancet 2005, 365(9460):702-710.

5. Eisenmann JC, Bartee RT, Wang MQ: Physical activity, TV viewing, and weight in U.S. youth: 1999 Youth Risk Behavior Survey. Obes Res 2002, 10(5):379-385.

6. Pediatrics AAo: American Academy of Pediatrics: Children, adolescents, and television. Pediatrics 200I, 107(2):423-426.

7. Shapira NA, Goldsmith TD, Keck PE Jr, Khosla UM, McElroy SL: Psychiatric features of individuals with problematic internet use. J Affect Disord 2000, 57(I-3):267-272.

8. Shapira NA, Lessig MC, Goldsmith TD, Szabo ST, Lazoritz M, Gold MS, Stein DJ: Problematic internet use: proposed classification and diagnostic criteria. Depress Anxiety 2003, I 7(4):207-216.

9. Yoo HJ, Cho SC, Ha J, Yune SK, Kim SJ, Hwang J, Chung A, Sung YH, Lyoo IK: Attention deficit hyperactivity symptoms and internet addiction. Psychiatry Clin Neurosci 2004, 58(5):487-494.

10. Tejeiro Salguero RA, Moran RM: Measuring problem video game playing in adolescents. Addiction 2002, 97(2I): 160I-1606.
II. Johansson A, Gotestam KG: Problems with computer games without monetary reward: similarity to pathological gambling. Psychol Rep 2004, 95(2):641-650.

12. Griffiths MD, Hunt N: Dependence on computer games by adolescents. Psychol Rep 1998, 82(2):475-480.

13. Johansson A, Gotestam KG: Internet addiction: characteristics of a questionnaire and prevalence in Norwegian youth (1218 years). Scand J Psychol 2004, 45(3):223-229.

14. Gentile DA, Lynch PJ, Linder JR, Walsh DA: The effects of violent video game habits on adolescent hostility, aggressive behaviors, and school performance. J Adolesc 2004, 27(1):5-22.

15. Nippold MA, Duthie JK, Larsen J: Literacy as a leisure activity: free-time preferences of older children and young adolescents. Lang Speech Hear Serv Sch 2005, 36(2):93-102.

16. Christakis DA, Ebel BE, Rivara FP, Zimmerman FJ: Television, video, and computer game usage in children under II years of age. J Pediatr 2004, I 45(5):652-656.

17. Wake M, Hesketh K, Waters E: Television, computer use and body mass index in Australian primary school children. J Paediatr Child Health 2003, 39(2): I30-134.

18. Vandewater EA, Shim MS, Caplovitz AG: Linking obesity and activity level with children's television and video game use. I Adolesc 2004, 27( I):7I-85.

19. Stettler N, Signer TM, Suter PM: Electronic games and environmental factors associated with childhood obesity in Switzerland. Obes Res 2004, I 2(6):896-903.

20. Anderson CA: An update on the effects of playing violent video games. J Adolesc 2004, 27(I): I I3-I 22.

21. Anderson CA, Bushman BJ: Effects of violent video games on aggressive behavior, aggressive cognition, aggressive affect, physiological arousal, and prosocial behavior: a meta-analytic review of the scientific literature. Psychol Sci 200I, I 2(5):353-359.

22. Haninger $K$, Thompson KM: Content and ratings of teen-rated video games. Jama 2004, 29 I(7):856-865.

23. Vaidya HJ: Playstation thumb. Lancet 2004, 363(94/4): 1080.

24. Lee $\mathrm{H}$ : A new case of fatal pulmonary thromboembolism associated with prolonged sitting at computer in Korea. Yonsei Med J 2004, 45(2):349-35I.

25. Kang JW, Kim H, Cho SH, Lee MK, Kim YD, Nan HM, Lee CH: The association of subjective stress, urinary catecholamine concentrations and PC game room use and musculoskeletal disorders of the upper limbs in young male Koreans. J Korean Med Sci 2003, 1 8(3):419-424.

26. Kasteleijn-Nolst Trenite DG, da Silva A, Ricci S, Binnie CD, Rubboli G, Tassinari CA, Segers JP: Video-game epilepsy: a European study. Epilepsia 1999, 40(Suppl 4):70-74.

27. Kasteleijn-Nolst Trenite DG, Martins da Silva A, Ricci S, Rubboli G, Tassinari CA, Lopes J, Bettencourt M, Oosting J, Segers JP: Video games are exciting: a European study of video game-induced seizures and epilepsy. Epileptic Disord 2002, 4(2): $|2|-\mid 28$.

28. Li X, Atkins MS: Early childhood computer experience and cognitive and motor development. Pediatrics 2004, II3(6): I7I5-I722.

29. Enochsson L, Isaksson B, Tour R, Kjellin A, Hedman L, Wredmark T, Tsai-Fellander $L$ : Visuospatial skills and computer game experience influence the performance of virtual endoscopy. J Gastrointest Surg 2004, 8(7):876-882. discussion 882.

30. Latessa R, Harman JH Jr, Hardee S, Scmidt-Dalton T: Teaching medicine using interactive games: development of the "stumpers" quiz show game. Fam Med 2004, 36(9):6I6.

31. Rosenberg BH, Landsittel D, Averch TD: Can video games be used to predict or improve laparoscopic skills? J Endourol 2005, 19(3):372-376.

32. Birnbaum HG, Kessler RC, Lowe SW, Secnik K, Greenberg PE, Leong SA, Swensen AR: Costs of attention deficit-hyperactivity disor$\operatorname{der}$ (ADHD) in the US: excess costs of persons with ADHD and their family members in 2000. Curr Med Res Opin 2005, 2I(2): 195-206.

33. Swensen AR, Birnbaum HG, Secnik K, Marynchenko M, Greenberg P, Claxton A: Attention-deficit/hyperactivity disorder: increased costs for patients and their families. J Am Acad Child Adolesc Psychiatry 2003, 42(12): |4| 5 - | 423.

34. McGough JJ, McCracken JT: Assessment of attention deficit hyperactivity disorder: a review of recent literature. Curr Opin Pediatr 2000, 1 2(4):319-324. 
35. Conners CK, Sitarenios G, Parker JD, Epstein JN: The revised Conners' Parent Rating Scale (CPRS-R): factor structure, reliability, and criterion validity. J Abnorm Child Psychol 1998, 26(4):257-268.

36. Widyanto L, McMurran M: The psychometric properties of the internet addiction test. Cyberpsychol Behav 2004, 7(4):443-450.

37. Hudziak JJ, Derks EM, Althoff RR, Rettew DC, Boomsma DI: The genetic and environmental contributions to attention deficit hyperactivity disorder as measured by the conners' rating scales - revised. Am J Psychiatry 2005, 162(9): 16I4-1620.

38. Dey AN, Schiller JS, Tai DA: Summary health statistics for U.S. children: National Health Interview Survey, 2002. Vital Health Stat 10 2004: I-78.

Publish with Bio Med Central and every scientist can read your work free of charge

"BioMed Central will be the most significant development for disseminating the results of biomedical research in our lifetime. "

Sir Paul Nurse, Cancer Research UK

Your research papers will be:

- available free of charge to the entire biomedical community

- peer reviewed and published immediately upon acceptance

- cited in PubMed and archived on PubMed Central

- yours - you keep the copyright

Submit your manuscript here:

http://www.biomedcentral.com/info/publishing_adv.asp
BioMedcentral 